\title{
KAITOS PROCESO IR POKYČIŲ VALDYMO SINERGIJA UGDYMO İSTAIGOSE: METODOLOGINIS TYRIMO KONSTRUKTAS
}

\author{
Asta Valackienė, Vaida Želnienè \\ Kauno technologijos universitetas
}

\begin{abstract}
Anotacija
Straipsnyje siūloma mokslinè diskusija, siekiant aptarti kaitos proceso ir pokyčių valdymo sinergiją švietimo sistemoje, pažymint, kad du paskiri veiksniai, veikdami kartu, duoda didesnị poveikị ir socioekonominę grąžą / naudą. Aptariamas kaitos proceso ir pokyčių valdymo konceptas ugdymo ịstaigose. Pažymima, kad kaitos procese ypač svarbu tinkamai suplanuoti pokyčius ir numatyti rezultatus, ne mažiau svarbu suprasti, kaip visi minèti pokyčiai bus igyvendinti. Diskusiniai klausimai: kada kaitos procesai vyksta teisingai? Atsakymas: kai vadybiškai teisingai valdomi pokyčiai. Kaip bus užtikrinamas kaitos proceso vyksmas? Atsakymas: kaitos proceso vyksmas vyksta pokyčių valdymo lauke - sistemiškai, igalinant visus pokyčių valdymo procesus. Straipsnyje pristatomas tyrimo metodologinis konstruktas, atskleidžiant kaitos proceso ir pokyčių valdymo sinergiją, remiantis pasirinktos ugdymo įstaigos pavyzdžiu.

PAGRINDINIAI ŽODŽIAI: kaitos procesas, švietimo kaitos ir pokyčiu valdymo sinergija, metodologija.
\end{abstract}

\begin{abstract}
This article invites for a scientific discussion while discussing the synergy between the process of change and the change management in the system of education and emphasizing that two different factors give larger impact and socioeconomic benefits if they are used together. In this article the concept of the process of change and change management in the educational institutions is analysed. It is noted that in a process of change it is very important to properly plan the changes and to identify the expected results but also it is very important to understand how all above mentioned process will be implemented. Questions to discuss: when the processes of change are implemented properly? Answer: when the changes are managed properly. How to ensure the implementation of the process of change management? Answer: the implementation of the process of change management is held in a field of change management systematically enabling all the processes of change management. The methodological construct of the research is presented in this article, revealing the synergy of the process of change and change management of the chosen school.

KEY WORDS: the process of change, the synergy between the process of change and the change management, methodology.
\end{abstract}

DOI: http://dx.doi.org/10.15181/tbb.v79i2.1777

\section{İžanga}

Lietuva, tapusi Europos ekonominio bendradarbiavimo organizacijos (EBPO) nare, turi reflektuoti socialinès kaitos procesą ir igyvendinti šios organizacijos pateiktas rekomendacijas švietimo srityje. Visų pirma: susitelkti ties pagrindinio ugdymo mokymosi rezultatų gerinimu, kelti mokytojo profesijos prestižą, peržiūrèti mokyklų finansavimo modelị, atkreipti dèmesị ị vertinimo sistemą. Šalia rimtų mokslo pasiekimų, stebimas mažèjantis Lietuvos moksleivių raštingumas, 
lyginant su kitų ES valstybių bendraamžiais. Kita vertus, mažèjantis gyventojų skaičius Lietuvoje lemia mažèjantị ugdymo ịstaigu skaičių Tad akivaizdu, kad socialinè kaita tarptautiniu ir nacionaliniu lygmenimis skatina diskutuoti apie pokyčių valdymo lauką šalies švietimo sistemoje. Čia svarbu atsakyti ị probleminị klausimą, kas lemia kaitos proceso ir pokyčių valdymo sinergiją ugdymo ịstaigose? Straipsnio autoriai skatina mokslinę diskusiją ir kviečia paanalizuoti, kodèl ugdymo ịstaigų vykdomus pokyčius lemia panašūs vidaus ir išorès veiksniai, bet kaitos procesas ir jo rezultatai ugdymo įstaigose skiriasi. Straipsnio autoriai mano, kad organizacijos kaitos procese lemiamą vaidmenị vaidina sistemiškas pokyčių valdymas. Tokia straipsnio autorių loginė pozicija kitų mokslininkų darbuose nepakankamai išreikšta. Nors pokyčiams organizacijose, iskaitant ir viešaji sektorių, mokslininkai skiria daug dèmesio, tyrimų, kurie susietų valstybès švietimo sistemos pokyčių ígyvendinimo sėkmę su konkrečios mokyklos pokyčių valdymu, neaptikta. Pažymètina, kad iki šiol netirtas švietimo kaitos proceso igyvendinimas ir nepasiūlyta konkrečių pokyčiu valdymo scenarijų regioniniu lygmeniu. Be to, pasigendama aiškesnio kaitos proceso ir pokyčių valdymo sinergijos teorinio struktūrinimo ir tyrimų konstruktų.

Straipsnio tikslas - pristatyti metodologinį tyrimo konstruktą, aptariant kaitos proceso ir pokyčių valdymo sinergiją ugdymo ịstaigose.

Tikslui pasiekti nubrèžiama loginè socialinio reiškinio analizės seka, atskleidžianti keliamus uždavinius: teoriškai pagrissti kaitos proceso ir pokyčių valdymo konceptą, atskleidžiant švietimo kaitos dėsningumus ir principus; išryškinti integruoto pokyčių valdymo modelio taikymą švietimo įstaigų kaitos procese; sukonstruoti tyrimo instrumentą.

Tikslo siekiama pasirinktais metodais: sisteminè mokslinès literatūros analizè, diskursyvi tiriamos organizacijos dokumentų apžvalga.

Tikimasi, kad straipsnyje keliami diskusiniai klausimai ir pristatomas metodologinis tyrimo konstruktas paskatins mokslines diskusijas, t. y. kaitos proceso igyvendinimo ir pokyčių valdymo švietimo sistemoje klausimų aptarimą.

\section{Kaitos proceso ir pokyčių valdymo konceptas, atskleidžiant švietimo kaitos ir pokyčių valdymo sinergiją}

„Kaita savaime nėra nei pažangus, nei novatoriškas reiškinys, tai tiesiog perèjimas iš vienos būsenos ị kitą“ (Želvys, remdamasis Ellstrom, 1984, p. 18). Kaita dažnai yra nenuspejjama, jos neįmanoma visapusiškai kontroliuoti, bet galima paveikti: suteikti norimą tempą, pageidautiną kryptị ar priimtinesnị pobūdị. Kaitos sąvoka vartojama įvairiose srityse ir kontekstuose. Tokia klasikinè kaitos samprata tiktų ir švietimo kaitai apibūdinti. Tačiau švietimo santykis su kaita šiek tiek su- 
dètingesnis, nes apima daugiau dedamujų ir visą visuomenę. Švietimo kaita gali būti vertinama kaip sąmoningų ir kryptingų pastangų darinys ir kaip natūralus socialinių dėsnių nulemtas procesas, kurio negalima pradèti ar stabdyti, o tik suteikti norimą tempą, pageidaujamą kryptị ir priimtinesnị pobūdị (Želvys, 1998). Pasak M. Wallace'o ir P. Pocklingtono (2001, p. 45), „švietimo sistemos pokyčiai yra sudètingi, nes susiję su žmonėmis, nors žmonès ne visada gali rinktis aplinkybes, kuriomis tie pokyčiai vyksta. Jie paveikia asmenis ir jų grupes, kurie skirtingai suvokia vykstančius pokyčius, puoselëja skirtingus lūkesčius, turi skirtingų galių, kurias gali pasitelkti, siekdami igyvendinti pokyčius, veikia didžiulejje daugiasluoksnèje švietimo sistemoje, kur nuolat sąveikauja su tais, kurių niekada nėra matę, ir yra veikiami pasaulyje vyraujančių ekonominių tendencijų“.

L. Jovaiša „Enciklopediniame edukologijos žodyne“ kaitos sampratą aiškina taip: „Kaita - procesas, kai vyksta institucijų, jų veiklos turinio, organizacijos ir būdų persitvarkymas pagal naujus tikslus, programas ir metodus, atsižvelgiant $\mathfrak{i}$ besikeičiančias ekonomines, politines, socialines sąlygas; švietimo sistemos, mokyklų, ugdymo turinio, ugdymo mokslo, ugdymo technologijos arba praktikos keitimasis tam tikru laikotarpiu“ (Jovaiša, 2007, p. 111). D. Hopkinsas, M. Ainscowas, M. Westas (1998) švietimo kaita apibūdina kaip sudètingą reiškinị, tiesiogiai nukreiptą ị rezultatą - mokinių pasiekimus. Šie autoriai pažymi kaitos, kaip proceso, vientisumą ir visapusiškumą. Jų požiūriu, poveikio mokinių laimèjimams galima tikètis tada, kai kaita apima visą įvykių grandinę: nuo švietimo politikos iki veiklos klasèje (Hopkins ir kt., 1998).

L. Stollas ir D. Finkas (1998) švietimo kaitą sieja su pažanga. Jų požiūriu, nors ir ne visada kaita lemia pažangą, pastaroji visada reiškia kaitą. M. Fullanas (1998) ižzvelgia glaudų mokyklos tobulinimo ir kaitos ryšį. Jo manymu, sẻkmingą mokyklos tobulinimą lemia kaitos esmès suvokimas praktiniu lygiu ir tinkamai parinkta strategija, garantuojanti naudingus pokyčius. Tad pastarasis autorius orientuoja $\underset{i}{ }$ pokyčių strategini valdymą. Lietuvių mokslininkai (pvz., Gečienè, 2003) pabrèžia, kad šiandieninè mokykla,, kaip organizacija yra nuolatinès kaitos būsenos. Pasak R. Želvio (2003), mokykla turi keistis taip, kaip keičiasi ją supanti aplinka. Autorius mini šiuos kaitos proceso elementus: procedūros, atliekami darbai, nauji santykiai, naujos taisyklès, išoriniai veiksniai, kurie nepriklauso nuo kaitos turinio, ir visa tai, kas skatina pokyčius arba kelia abejonių. Svarstoma, kas skatina tobuleti ir kaip to siekti. Keliamas klausimas, kas yra mokyklos tobulinimas, nuo ko jis prasideda, koks jo ryšys su kaita, ar esama sąlygų, kurios tobulinimą skatintų arba jam trukdytų. O. Monkevičienès (2008) teigimu, švietimo kaita - tai nuolatinis, nenutrūkstamas, nuo paties švietimo neatsiejamas reiškinys, nulemtas visuomenès poreikių, jos nuostatų ir vertybinių orientacijų. Anot R. Kubilienès (2003), mokyklos tobulinimas yra ar bent jau turètų būti jos pačios rūpestis. Su- 
dètingiausias kaitos aspektas - išlaikyti išorès primetamą tempą ir su juo suspèti. Tam, kad mokykla tobulètų ir išliktų, jos mokymosi tempas turi būti didesnis nei išorès pokyčių greitis. V. Targamadzės (1996) nuomone, mokykla, noredama ir toliau atlikti socializacijos funkciją, turi keistis taip, kaip keičiasi jos aplinka. Todèl švietimo ịstaigose administravimas keičiamas kokybės vadyba, atliekamas vidinis ir išorinis auditai, kolegialiai rengiamos strategijos bei plètros planai. Kita vertus, būdama savarankiška, t. y. nepriklausoma nuo aplinkos, mokykla kartais susikuria kaitą ribojančių barjerų. Pedagoginè bendruomenè dažnai pasirengusi gintis nuo už ịstaigos sienų vykstančios kaitos, kartais jai net priešinasi, nenorèdama pripažinti kaitos būtinumo savo institucijos viduje. Tiek edukologai teoretikai, tiek pedagogai praktikai, pasak R. Želvio (1999), neretai gana paviršutiniškai suvokia sudètingus kaitos procesus.

Mokslinejje literatūroje yra įvairių kaitos sąvokos aiškinimų. R. Jucevičius ir kt. (2003) teigia, kad kaita - tai pokyčius apibūdinantis procesas. Šie autoriai pokytị traktuoja kaip kaitos komponentą, t. y. kaitą sudaro pokyčiai. R. Želvio (1999) pateikta samprata - analogiška. Jo teigimu, kaita tapo ịprastu reiškiniu, pokyčiai gyvenimo norma ir kuo toliau, tuo sparčiau jie vyksta. Taigi kaitos pagrindas pokyčiai.

Kaip teigia E. Bagdonas (2016), kaitos procese žmonès ir organizacijos tobulejja, skleidžia naujas mintis, savo veikloje ịgyvendina idejjas, keičia mąstymą, požiūrị ị ịvairius gyvenimo reiškinius. Anot R. Želvio (2003), pokyčiai švietime yra neišvengiami, juos skatina nuolat kintančios gyvenimo sąlygos, švietimo politikos pokyčiai, realybė, todèl svarbu nuspèti įvykius, būsimą švietimo politiką, dabartinių ugdymo institucijų perspektyvas po kelerių ar keliasdešimt metų. Siekiant išvengti nepageidaujamų kaitos proceso padarinių, svarbu aktyviai veikti kaitos procesą, t. y. kurti ugdymo institucijų ateities perspektyvas.

Kitas aspektas, aptariant kaitos sampratą, kurị mokslininkai kone vieningai pabrèžia, yra kaitos neišvengiamumas ir tai, kad asmuo ar organizacija su kaita besąlygiškai susiję: „Kaita yra neatsiejamybè. Kaita apima visa. Mūsų požiūryje ¡̣ kaitą, pasak T. S. Kuhno (1962), turi įvykti „,paradigmos poslinkis“. Tokie sampratos ir ịsitikinimų poslinkiai nèra lengvi, tačiau be jų mes ir toliau bejẻgiškai kapanosimès neišvengiamybės akivaizdoje. Kaita turètų rūpèti kiekvienam. Pokyčiai neturi mūsų užklupti, turime suprasti procesą, o supratę, imtis jị reguliuoti““ (Hopkins ir kt., 1998, p. 60). Bandymas stabdyti neišvengiamą kaitą gali lemti katastrofiškus padarinius. Ji vyksta nepaisant to, patinka mums tai ar ne. Taigi galime teigti, kad esame pasmerkti kaitai. D. Hopkinso ir kt. (1998) teigimu, kaita yra sudètingas reiškinys, tad norint ši procesą bent šiek tiek valdyti, pirma reikia ji perprasti. Mokslininkai (Hopkins, 1998; Želvys, 1999; Jucevičius, 2003), analizuodami kaitos procesus, skiria du jos tipus. Autorių teigimu, organizacijose 
kaita paprastai pasireiškia viena iš šių dviejų formų: natūrali kaita, t. y. nuoseklus, dažniausia nežymus perèjimas iš vieno būvio ị kitą, ir planinga kaita, kai siekiama sustabdyti savaiminę ịvykių raidą ir tam tikrą dieną, nutraukus ankstesnę veiklą, įvesti naują tvarką. Kaip minèta, kaita pasireiškia dviem formomis, jos šaltiniai, šių mokslininkų teigimu, paprastai taip pat yra dvejopi: išoriniai ir vidiniai. Dèl vidinio šaltinio teigiama, kad nesvarbu, ji pasireikš organizacijos ar individo lygmeniu, kaita suvokiama kaip natūrali arba organiška būsena. Ǐsorinę kaita dažniau planuoja švietimo politikai, tiksliau - nacionalinio lygmens švietimo politikai. Taigi mokyklą, kaip organizaciją, tokia kaita, jos pokyčiai, naujovès pasiekia iš išorès, kaip aukštesnès švietimo valdymo grandies valia, nurodanti, skatinanti ją priimti ir ịtvirtinti. Taigi mokyklai iškyla būtinybė reflektuoti kaitos procesą, valdyti išorès nulemtus ir vidinius pokyčiu procesus. Nuo kaitos tipo priklauso, kaip ji bus ịgyvendinama. Galime teigti, kad natūrali švietimo kaita vyksta kasdien. Jos neįmanoma sustabdyti, o per tam tikrą laiką îvykę pokyčiai paprastai pastebimi tik pažvelgus atgal (Hopkins, 1998). Planinga švietimo kaita apima tikslingus pokyčius, naujovių itvirtinimą, jos tikslas - gerinti švietimo kokybę, valdyti mokykloje vykdomus pokyčius, atsižvelgiant ị iškeltus kaitos tikslus ir reikalavimus.

Turime pastebèti, kad kaitos ir pokyčiu valdymo sinergija tampa akivaizdi. Kaitos procese svarbu tinkamai suplanuoti pokyčius ir numatyti rezultatus. Ne mažiau svarbu žinoti, kaip minètas procesas igyvendinamas. Siekiant, kad organizacijoje neišvengiamas kaitos procesas būtų aktyvesnis, mažiau būtų priešinamasi pokyčiams ir tame procese dalyvautų visi organizacijos nariai, svarbiausias organizacijai keliamas uždavinys - tinkama komunikacija.

P. Dainty ir A. Kakabadse (1990) kaitos proceso ịgyvendinimą apibrèžia aštuoniais žingsniais. Autoriai pastebi, kad kiekviename iš tų žingsnių pokyčius igyvendinantys organizacijų atstovai gali susidurti su tam tikromis kliūtimis ar sunkumais: apsisprendimas, ar pokyčiu reikia. Šiuo atveju svarbu stebėti, ar keliami organizacijos tikslai ir pasiekiami rezultatai nesiskiria. Jei tokių skirtumu atsiranda, organizacijos lyderiai atsakingai turètų imtis pokyčių.

1. Poreikio veikti pripažinimas. Nors organizacija pripažista, kad jos išsikelti tikslai ir pasiekiami rezultatai skiriasi, ji ne visada pasirengusi imtis veiksmų, kad situacija pagerètų. Dėl to svarbu, kad pokyčių lyderiai atkakliai siektų ịtikinti organizacijos vadovus pripažinti veiksmų iggyvendinti pokyčius būtinybę.

2. Problemų diagnozavimas. Šiame etape svarbu atkreipti dèmesị ị tai, kad problemos keičiasi, be to, pasitaiko situacijų, kad iš pirmo žvilgsnio diagnozuota problema tèra gilesnès problemos pasekmè, taigi būtina užtikrinti lankstų požiūrị ị problemos apibrèžimą. 
3. Pokyčių tikslų apibrèžimas. Atkreiptinas dèmesys, kad dažnai pokyčių tikslų apibrèžimą lemia organizacijoje veikiančių interesų grupių ar asmenų įvairovè, tad jam įtaką daro šių grupių konfliktai ar politinis elgesys.

4. Pokyčiu programos parinkimas priklauso nuo to, kokias problemas pokyčiais ketinama spręsti. Šiame etape priimami sprendimai dẻl pokyčių igyvendinimo laiko, strategijos, metodų.

5. Pokyčių igyvendinimas. Šiame etape svarbu matyti visa apimantị pokyčių paveikslą, t. y. organizacijos narius vienijančius simbolius ir pokyčių poveikị jiems. Be to, būtina ịvertinti, kokị poveikị pokyčiai organizacijos narių lygiu turès ir organizacijos vadovybei.

6. Tinkamos atmosferos pokyčiams vykti sukūrimas. Svarbu užtikrinti, kad organizacijos nariai kuo mažiau priešinsis pokyčiams, kitaip kaitos procesas, tikètina, baigsis nesèkme.

7. Pokyčių veiksmingumo įvertinimas.

8. Prireikus, pokyčių strategijos modifikavimas. Pabrěžiama, kad pokyčiu programų nereikia nuolat modifikuoti, bet būtina nuolat vertinti.

Pasak P. Loticho (2017), kad kaitos procesas organizacijoje būtų sẻkmingas, svarbūs šie veiksniai:

1. Organizacijos vadovybès parama pokyčiams. Darbuotojai būna palankiau nusiteikę pokyčių atžvilgiu, jei mato, kad vadovai nedviprasmiškai palaiko diegiamas naujoves.

2. Pokyčių pagrindas. Svarbu, kad pokyčiai organizacijoje remtųsi tam tikrais pagrịstais rodikliais, t. y. statistine informacija, strateginio planavimo rezultatais ir pan.

3. Darbuotojų ịtraukimas ị kaitos procesą. Darbuotojai turi gauti tinkamą informaciją ir paaiškinimus apie vykstančius pokyčius, ypač tiesiogiai susijusią su konkretaus darbuotojo užduotimis. Be to, organizacijos nariai ir patys dažnai turi pasiūlymų, kaip būtų galima tobulinti kaitos procesą.

4. Komunikacija apie pokyčius (organizacijos viduje ir išorèje). Ji turi būti struktūruota ir sistemiška. Proaktyvi komunikacija mažina organizacijos narių pasipriešinimą pokyčiams.

5. Pokyčių igyvendinimas. Būtinas aiškus pokyčių igyvendinimo planas, t. y. tvarkaraštis, kad organizacijos nariai žinotu, kaip vyks suplanuoti pokyčiai.

6. Kita informacija. Kai pokyčiai igyvendinami, svarbu įvertinti kaitos procesą, ar pasiekti norimi rezultatai. 
7. Kliūčių šalinimas. Organizacijos darbuotojams kaitos procese kyla ịvairių kliūčių, tad vadovybė privalo užtikrinti sąlygas, kad darbuotojai pokyčius iggyvendintų be sunkumų.

8. Šventè. Svarbu paminèti sẻkmingai ịvykusius pokyčius. Net ir mažų pokyčių šventimas gali ịkvejpti didesnius pokyčius ir paskatinti organizacijos narius nesipriešinti naujovèms.

R. Smith (2014) skiria keletą technikų, kurios padeda užtikrinti sklandų ir sèkmingą kaitos procesą:

- Tinkamo lyderio, vykdysiančio pokyčius, parinkimas. Jis ne tik turi suprasti būsimų pokyčiu kainą, bet ir gebèti igyti visų organizacijos narių pasitikèjimą. Pokyčių lyderis turi žinoti, kaip valdoma organizacija, kartu suprasti, kad organizacijos nariams pokyčiai kelia nerimą.

- Stiprios pokyčius vykdysiančios komandos subūrimas. Tokią komandą sudaro organizacijos nariai iš įvairių organizacijos lygių. Tai padeda užmegzti ryši tarp visų darbuotojų ir vadovų.

- Darbuotojų / organizacijos narių ịtraukimas. Tai užtikrina kaitos proceso sėkmę. Svarbu darbuotojams nuolat ir tinkamai paaiškinti, kokie pokyčiai planuojami, kaip jie bus iggyvendinti ir kokių rezultatų siekiama.

Ypač aukšti reikalavimai organizacijų kaitos procese, siekiant sėkmingai valdyti pokyčius, keliami organizacijų vadovams. Svarbu, kad jie taptų pokyčių lyderiais, įsipareigotų jiems, būtų naujų elgesio modelių pavyzdys, pakankamai laiko ir energijos skirtu pokyčiams remti. Mokslininkai (Lindsay, Smit, 2018) nurodo septynis pokyčių lyderių veiksmus, kurie būtini, siekiant sẻkmingai igyvendinti kaitos procesą: nuo pirmos dienos planuojama, siekiant ilgalaikių ir tvarių pokyčių; aiškus nuosavybès jausmas ir ịsipareigojimas pokyčiams visuose organizacijos lygmenyse; aiški atskaitomybė už specifinius veiksmus per visą kaitos procesą; nuolatinis tobulèjimas kaitos proceso metu ir greita reakcija, prireikus alternatyvaus kaitos plano; siekiama sutelkti organizaciją strateginiams pokyčiams.

Siekiant paaiškinti švietimo kaitos ir pokyčių valdymo sinergiją, būtina aptarti kaitos principus. Švietimo kaitos teoretikas M. Fullanas (1993) suformulavo kaitos principus, pavadinęs juos pamokomis, kurios nulemtos naujosios dinamišku pokyčių paradigmos. Jo teigimu, pamokos turi būti suvokiamos visos drauge, kaip visuma, nes atskirai nè viena jų nebus naudinga. R. Želvio (1999) nuomone, šie principai ypač svarbūs, siekiant suprasti dabartinès švietimo kaitos dėsningumus: kuo sudètingesnè kaita, tuo mažiau mes ją galime reguliuoti, klystume, jei manytume gali ją valdyti. Vykstant visuotiniams pokyčiams, dalies procesų eiga natūrali, nevaldoma ir nepriklauso nuo mūsų valios bei pastangų. Galime, 
pavyzdžiui, pakeisti švietimo organizacijų struktūrą, ugdymo turinį, teisinio reguliavimo principus ir kt., bet negalime priversti žmonių keistis. Nepakeitę mąstymo ir igūdžių, pokyčius norima linkme galèsime kreipti labai ribotai: jei kažkas ir pasikeis, pokyčiai bus paviršutiniški.

Kaita nèra linijinio pobūdžio, ji neapibrěžta, kartais - ir kupina netikètumų: nerimas, sunkumai ir nežinomybès baimè visada būdingi kaitos procesui, ypač pradinèje stadijoje. Sunkumai pradinèje stadijoje garantuoti. Nenuspèjami būna ir vèlesni etapai.

Kaitos procese visada egzistuoja laimès aspektas: kartais, nepaisant visko, mus lydi sèkmè, kartais nesiseka.

Problemos yra mūsų draugai. Jos kaitos procese neišvengiamos, be jų mes negalime nieko išmokti ir tikètis sèkmės. Tik spręsdami problemas galime atrasti kūrybiškus sprendimus. Jei kyla problemų, vadinasi, pokyčiai tikrai vyksta. Jei ankstyvosios kaitos stadijos praeina lengvai, tai gali rodyti, kad kaita paviršutiniška. Taigi konfliktas yra esminis kaitos komponentas.

Vizija ir strateginis planavimas neturi būti pernelyg ankstyvi. Popieriuje sukurta vizija neilgaamžè: sudètingos kaitos sąlygomis negalime vien tik kurti teorijų ar mūsų norus ịkūnijančių vizijų. Vizija išplaukia iš to, kas praktiškai vyksta. Be to, tam, kad darbas vyktų sėkmingai, būtina kolektyvinè vizija. Siekiant suformuoti bendrą, visiems priimtiną viziją, reikia laiko. Pernelyg ankstyvas strateginis planavimas taip pat kvestionuotinas. Jis gali klaidinti. S. Sarasono (1990) teigimu, švietimo kaitos inicijavimas pagal iš anksto sudarytą veiklos planą nuo pat pradžiu pasmerktas nesékmei.

Individualizmas ir kolektyvizmas yra vienodai svarbūs. Tam, kad švietimo kaita vyktų norima linkme, būtina ugdyti pedagogų gebejjimą savarankiškai mąstyti, dirbti ir kartu siekti bendrų tikslų.

Nei vienpusè centralizacija, nei decentralizacija neveiksmingos. Pernelyg didelè centralizacija reiškia perdètą kontrolę, decentralizacija - chaosą. Švietimo reformų istorija atskleide, kad ,iš viršaus nuleisti“ pokyčiai neveiksmingi. Kita vertus, , ,iš apačios“ inicijuojami projektai taip pat žlunga, nesulaukę aukštesnių švietimo grandžių palaikymo. Kaitos procesai turi vienu metu vykti ir „,iš viršaus“", ir , ,iš apačios“.

Ryšiai su išorine aplinka turi lemiamą reikšmę. Švietimo kaita neišvengiamai vyksta plačiame socialiniame ir ekonominiame kontekste (Želvys, remdamasis Husen, 1990). Jei ignoruosime kaitą, kuri vyksta už mokyklos sienų, nesugebėsime iš esmès paveikti kaitos ir pačioje mokykloje. Taigi tiek išorinę, tiek vidinę aplinką būtina vienodai rimtai vertinti. 
Kaitos procese turi dalyvauti visi. Esminių pokyčiu galima pasiekti tik visiems pedagogams imantis darbinès aplinkos keitimo veiksmų. Kaitoje turi dalyvauti kiekvienas vienaip ar kitaip su švietimu susijęs asmuo (Želvys, 1999).

R. Želvys (1999, p. 49) aptare kito kaitos teoretiko D. Hargreaveso (2008) suformuluotus šešis švietimo kaitos principus ir pastebejjo, kad jie gana tikslingai nukreipti ị praktinį pokyčio valdymą. Aprašyti šie švietimo kaitos principai:

- Tikslų reliatyvumas: sudètingos ir sparčios kaitos laikotarpiu geriau užsibrèžti laikinus ir mažiau apibrèžtus tikslus, nes juos neišvengiamai reikès nuolat peržiūrèti ir papildyti.

- Emocinis aspektas daro didelę itaką kaitos procesui. Jei ignoruosime emocinius reformos aspektus, jausmai ir emocijos vis tiek prasiverš ir veiks racionaliai priimtų sprendimų igyvendinimą.

- Politikos igyvendinimas: nors sisteminès reformos paprastai inicijuojamos visos šalies mastu, pokyčiu sèkmè priklausys nuo to, kaip jie bus suprasti ir priimti kiekvienoje švietimo institucijoje. Todèl politiniai sprendimai turi būti priimami konkrečiose darbo vietose.

- Rekultūrizacija: siekiant planingos kaitos, būtina puoselèti bendradarbiavimo kultūrą tarp tuo metu kolektyvą sudarančių žmonių.

- Restruktūrizacija: kultūros egzistuoja ne vakuume, jos apibrèžtos laike ir erdvėje. Nors kaita prasideda nuo rekultūrizacijos, nedera pamiršti ir struktūrinių pokyčių, nes besiformuojančių santykių pobūdis priklauso ir nuo struktūrų.

- Organizacijų mokymasis: bendras darbas - vienas iš mokymosi šaltinių. Bendradarbiavimo kultūra individualų mokymąsi paverčia kolektyviniu procesu.

Mokslinėje literatūroje (Bennis ir kt., 1998) struktūrinami kaitos modeliai, suteikiantys, kaip teigia autoriai, „veiksmo pagrindą“ ir skiria tris kaitos modeliu grupes:

- Jègos, prievartinis - direktyvus (istatymiškas) ir labai autoritariškas. Komunikacija - tik vienpusé.

- Normatyvinis perauklèjimo, nukreiptas i praktiku grupès nuostatas, normas ir nuomones, igyvendinamas dirbant grupeje; pabrežiamas abipusis asmenų bendravimas. Komunikacija - abipusè.

- Racionalusis empirinis, remiasi profesionalų žinojimu, praktiko protu ar intelektu. Komunikacija iš esmès taip pat yra vienpusė: knygos, paskaitos, reklama.

Šios kaitos modelių klasifikacijos pagrindas - žinių apie kaitą sklaidos būdas. 
Kitaip kaitos modelius klasifikuoja D. Hopkinsas (1984), atsakydamas, iš kur kyla kaitos ideja. Jis įvardija ịsiūlytaji ir pritaikomaji modelius. Įsiūlytasis modelis remiasi ,iš viršaus“ nuleidžiama, arba linijine kaita, skatinama valdžios, nepripažịstant mokyklos situacijos savitumo, reikalaujant besąlygiškai ịgyvendinti numatytus pokyčius. Pritaikomasis modelis leistų ir pageidautų, kad vadovaudamosi „iš viršaus“, t. y. nacionalinio lygmens, kylančiomis pokyčio idejjomis mokyklos atsižvelgtų ị savo konkrečią situaciją, o gebẻjimas keistis būtu išugdytas pačioje mokykloje. Šitaip klasifikuojami kaitos modeliai neabejotinai sietini su anksčiau aptartais trimis modeliais.

Apibendrinant teorines ịžvalgas apie kaitos proceso įgyvendinimą, galima teigti, kad tai yra sudètingas, išorinių ir vidinių veiksnių veikiamas procesas. Kad jis vyktų sėkmingai, o organizacija sulauktų norimų pokyčių rezultatų, pokyčių lyderiai pirmiausia turi užtikrinti tinkamą komunikaciją. Svarbu ne tik turèti organizacijos kaitos viziją, pasibaigus pokyčių proceso igyvendinimui, bet ir nuolat tą procesą vertinti, sudarant kaitos ir pokyčiu tęstinumo programą. Reflektuojant švietimo kaitos sampratą, švietimo kaitos dėsningumus ir principus, galima teigti, kad švietimo kaita - labai sudètingas ir nuolat vykstantis procesas, kurị sẻkmingai valdyti galima tik ịvertinus švietimo kaitos kompleksiškumą. Verta pastebèti, kad kaitos ir pokyčių valdymo sinergija tampa akivaizdžiu reiškiniu.

\section{Tyrimo konstravimo teorinės prielaidos. Integruoto pokyčių valdymo modelio taikymas švietimo ịstaigų kaitos procese}

Teorinis pagrindas, padejęs metodologiškai pasirengti empiriniam tyrimui, yra mokslininkų (Jacobs, van Witteloostuijn, Christe-Zeyse, 2013) pasiūlytas integruotas pokyčių valdymo teorinis modelis. Mūsų darbe jis pasirinktas dèl savo aprepties ir analizės lauko. Pateikiamas modelis apima tiek išorinius, tiek vidinius elementus (mikrolygiu - individualų supratimą apie pokyčius; mezo- - lyderystę ir organizacijos identitetą; makro- - aplinką). Modelio aprèptyje analizuojami tiek išoriniai (makrolygmens), tiek organizacijų kultūros (mezolygmens), tiek individualūs (mikrolygmens) pokyčiai.

- Mikrolygmuo: koncentruojamasi ị tai, kaip pokyčiai organizacijoje veikia žmogų.

- Mezolygmuo: tiriama, kaip pokyčiai organizacijoje veikia pastarosios identifikacijos ir institucionalizacijos procesus (ir kaip pastarieji veikia pokyčius organizacijoje).

- Makrolygmuo: analizuojama organizaciją supanti aplinka (Jacobs, van Witteloostuijn, Christe-Zeyse, 2013). 
Pasirinktas teorinis pagrindas igalins atskleisti kaitos proceso ir pokyčių valdymo sinergiją ugdymo ịstaigose. Minèti autoriai (Jacobs, van Witteloostuijn, Christe-Zeyse, 2013) atkreipia demesị i tai, kad organizacijos identitetas svarbus, siekiant, kad pokyčiai vyktų sėkmingai, kita vertus, tai gali lemti ir nesėkmę. Valdant organizacijos pokyčius būtina atsižvelgti ị organizacijos specifiką, nepamiršti kultūrinių ir institucinių skirtumų, dèl kurių vienoje organizacijoje pokyčiai gali būti sẻkmingi, kitoje - ne.

Straipsnio autoriai papildè teorinį modeli pokyčių procesų analize, ịtraukę naujas struktūrines dalis, kurios paaiškina pokyčių proceso elementus: laikotarpi prieš pokyčius (angl. input); laikotarpi, kai vyksta pokyčiai (angl. throughout); laikotarpi pokyčiams pasibaigus (angl. output). Straipsnio autoriai pažymi, kad visus tris pokyčiu proceso elementus vieną su kitu sieja organizacijos identitetas.

Laikotarpis prieš pokyčius (arba ịeiga) yra svarbiausias pokyčius nulemiantis arba esamos situacijos išlaikymą užtikrinantis veiksnys - atitikimas (angl. fit), kaip organizacijos vidaus bruožai dera su aplinka. Keičiantis aplinkai, atitikimo vis mažiau, todèl organizacijai kyla poreikis keistis ir vẻl prisitaikyti prie aplinkos. Norint ịvertinti veiksnius, kurie gali paskatinti pokyčius organizacijoje, vertinamos išorès galimybės ir grèsmès, stipriosios ir silpnosios vidinės pusės, t. $\mathrm{y}$. bus atliekama pasirinktos ugdymo ịstaigos $\mathrm{X}$ regione $S S G G$ analizé, kurią galima suskaidyti ị tris etapus:

I etapas: pokyčiams ịgyvendinti, jų sėkmei užtikrinti svarbi makroaplinka. Jos poveikis pokyčiams vertinamas, atliekant politinių, ekonominių, visuomeninių, technologinių ir ịstatymo leidimo klausimų analizę (PEVTL).

II etapas: tam, kad analizè būtų visa apimanti, būtina ịvertinti organizacijos vidines stiprybes ir silpnybes - turtą, gebẻjimus, kompetencijas, išteklius (TGKI).

III etape apibendrinami aukščiau aprašyti vertinimai ir daroma išvada, kaip organizacija ir išorès aplinka viena kitą atitinka ar neatitinka (Jacobs, van Witteloostuijn, Christe-Zeyse, 2013).

Laikotarpis, kai vyksta pokyčiai: procesai vyksta organizacijos viduje, o pokyčius gali paskatinti tiek išoriniai veiksniai, tiek organizacijų vadovai. Pažymètina, kad, priešingai nei įeigos, šiuo laikotarpiu supratimas apie atitikimą su aplinka yra subjektyvus. Šiame etape svarbų vaidmenį vaidina lyderis: stiprina pokyčių legitimumą, išlaiko ịsipareigojimus visame kaitos procese.

Laikotarpis pokyčiams pasibaigus (arba išeiga): vertinama, kaip pokyčiai pakeitė organizacijos veiklą: jie buvo teigiami, neutralūs ar neigiami. Svarbu pažymèti jų svarbą išorèje formuojamam organizacijos legitimumui ir vidiniam jos identitetui (Jacobs, van Witteloostuijn, Christe-Zeyse, 2013). 


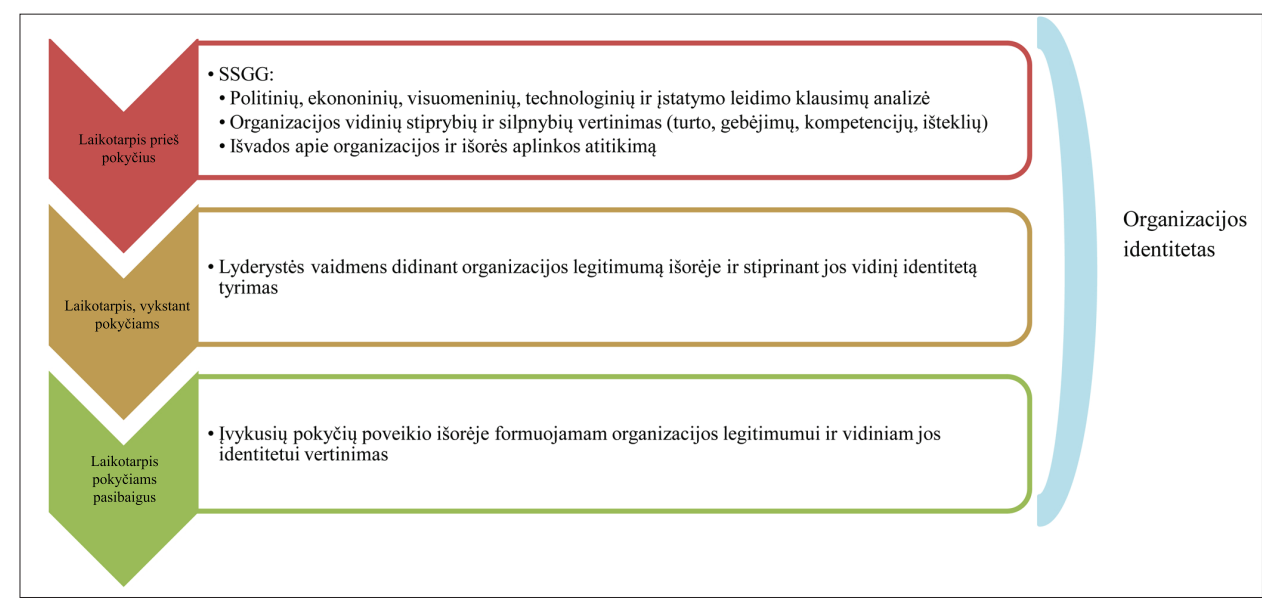

1. pav. Integruotas pokyčių valdymo teorinis modelis (adaptuota remiantis Jacobs, van Witteloostuijn, Christe-Zeyse, 2013)

Svarbu pastebèti, kad vienas svarbiausių organizacijos kaitos reikalavimų yra sẻkmingas pokyčių igyvendinimas. Siekiant užtikrinti švietimo kaitos tvarumą, pokyčiai turi būti apmąstyti ir vykdomi nuosekliai, t. y. sistemiškai.

Pokyčių sistemiškumo ugdymo įstaigose raiškos, užtikrinant kaitos tvarumą, teorinèms įžvalgoms konstruoti pasitelkta mokslininkų (Jenlink ir kt., 1998; Mason, 2016) kompleksiškumo (angl. complexity) teorija, kuri aiškina, kad raktas i sėkmingus ir tvarius pokyčius - daugelio tam tikrą sistemą sudarančių elementų ir naujų iniciatyvų tarpusavio sąveika, o ne pavienès iniciatyvos. Tuo remdamasis M. Masonas (2016) teigia, kad vykdant pokyčius švietimo sistemoje svarbu dèmesị kreipti ị visus šią sistemą sudarančius elementus. Siekiant pokyčių tvarumo, būtina ne tik ekonominių, kultūrinių, politinių ir kitų veiksnių sąveika, bet ir sistemą sudarančių elementų kritinè masè. Kompleksiškumo teorija teigia, kad konkrečiai sistemai pasiekus aukštą kompleksiškumo lygị (arba kritinę masę) prasideda pereinamasis laikotarpis, kurio metu sistemos elementai tarpusavyje sąveikauja. Šio proceso metu atsiranda naujų elementų, o senieji gali pasikeisti.

P. M. Jenlinkas ir kt. (1998) aptaria ryšius tarp švietimo sistemos ir jos bendruomenès (tèvų, darbuotojų, ịvairių organizacijų). M. Masonas (2016) pažymi, kad švietimo sistemoje veikia daugybė elementų ir veikejjų: mokiniai, jų tèvai, mokytojai, bendruomenių lyderiai, valstybès institucijos, ekonominè ir politinè valstybès struktūra, verslo ir nevyriausybinès organizacijos, kt. Taigi norint, kad švietimo srityje vyktų pokyčiai, gali prireikti atitinkamų veiksmų kiekvienoje arba daugely- 
je šių susijusių sistemos lygmenų. Be to, autorius teigia, kad švietimo srityje negali būti izoliuoto ịsikišimo, nes pokyčiai vienoje srityje lems pokyčius kitose.

Remiantis P. M. Jenlinku ir kt. (1998), M. Masonu (2016) galima skirti šiuos siekiant sistemiškų pokyčių švietimo srityje būtinus elementus:

- Dèmesys vaikams ir jų ateičiai: visų sisteminių pokyčių tikslas turètų būti mokymosi ir asmeninio vystymosi pažanga.

- Sisteminis mąstymas: pokyčių dalyvių požiūris ị švietimo sistemą turètų būti visa apimantis, kad geriau perprastų sistemos elementų tarpusavio priklausomumą.

- İtraukimas: ị procesą turi būti ịtraukti visi suinteresuoti asmenys.

- Dalyvių nuosavybès jausmas (ang. ownership): visi suinteresuoti asmenys / grupès turi būti atsakingi už tam tikrą pokyčių dalị ir įnešti savo indèli i procesą.

- Kartu vykstanti evoliucija: vienu metu turi keistis ne tik švietimo sistema, bet ir bendruomenè, individas.

Norime pažymèti, kad sistemiškumas mūsų tyrimo konstrukte aiškinamas kaip planuotas, visus organizacijos narius apimantis pokyčių procesas, kurio metu pokyčiai pasireiškia daugelyje skirtingų sistemos lygmenų.

\section{Tyrimo konstrukto pristatymas}

Tyrime keliamas klausimas, kaip igyvendinamas kaitos procesas pokyčių valdymo aspektu pasirinktose bendrojo lavinimo mokyklose. Remdamiesi aukščiau aprašytais ir pagrįstais kaitos proceso bei pokyčių valdymo konceptų teoriniais konstruktais, pristatome tyrimo dimensijas, kriterijus ir rodiklius, kurie leistų įvertinti kaitos proceso ir pokyčių valdymo sinergiją tiriamosiose organizacijose.

Tyrimo tikslas: išanalizavus pasirinktų Ukmergès rajono ugdymo įstaigų pokyčių valdymo praktiką per apibrezžtą laikotarpi (2010-2016 m.), atskleisti, kaip vyksta kaitos procesas.

Tyrimo organizavimas. Tirti pasirinktas Ukmergès rajono bendrojo lavinimo mokyklas, kuriu tipas keitėi per pastaruosius penkerius metus. Nors svarbiausias mokyklų atrankos kriterijus - jų tipo pasikeitimas (darant prielaidą, kad šis procesas daro didžiausią ịtaką pokyčių poreikiui ir jų valdymui), atsižvelgta ir ị kitus aspektus: moksleivių ir mokytojų skaičiaus kaitą, tai, kad mokyklos būtų priskirtos Ukmergès rajonui. Kadangi iki šio pokyčio mokyklos buvo vidurinès, pasirinkta įvertinti, kaip pokyčiai ịgyvendinami gimnazijoje mieste, pagrindinejje mokykloje mieste ir gimnazijoje rajone. Pasirinktas tyrimo laikotarpis - 20102016 m. Šiuo laikotarpiu pastebimas ryškus mokinių skaičiaus mokyklose kiti- 
mas, be to, valstybès lygiu buvo priimti sprendimai dèl Lietuvos bendrojo ugdymo mokyklų pertvarkos. İvertinus tai, kad pokyčiai mokyklose nèra greiti, pasirinktas vidutinis laikotarpis, kad būtų galima matyti realų pokyčių valdymo procesą ir jo rezultatus.

Tyrimo uždaviniai: išanalizuoti ugdymo ịstaigų situaciją iki pokyčių, laikotarpi, kai vyko pokyčiai, ir laikotarpi pokyčius iggyvendinus. Ivvertinti kaitos proceso pasirinktose ugdymo ịstaigose ịgyvendinimą pokyčių valdymo kontekste (mikro-, mezo- ir makrolygmenimis) ir nustatyti jų sinergiją.

Tyrimo kriterijai:

1. Ugdymo ịstaigose generuojamos švietimo kaitos idejos, atliepiant švietimo kaitos dèsningumus ir principus.

2. Ugdymo įstaigose pokyčiams valdyti taikomas integruoto pokyčių valdymo modelis.

3. Ugdymo ịstaigose igyvendinamo kaitos proceso ir pokyčių valdymo sąveika.

Tyrimo rodikliai:

1. Ugdymo ịstaigose vykdomos švietimo kaitos priežasčių nustatymas.

2. Ugdymo ịstaigu pasiruošimas valdyti pokyčius.

3. Ugdymo ịstaigų įsitraukimas ị pokyčiu valdymo procesą.

4. Ugdymo įstaigose vykdomų pokyčių kompleksiškumas.

Empirinis tyrimas vykdytas trimis etapais:

I etapas. Atliekama ugdymo ịstaigų SSGG analizè: ịvertintas pokyčių būtinybę ugdymo ịstaigose lèmęs kontekstas (politinè, ekonominè, visuomeninè, technologinè ir kitu sričių aplinka); įstaigos gebẻjimas vykdyti pokyčius, t. y. išugdyti atitinkami gebejjimai, ịvertinti turimi finansiniai ir žmogiškieji ištekliai, pan.

II etapas. Atliekama atvejo studija ir iš dalies struktūruotas interviu. Šiame etape bus tiriama, kokie procesai vykdant pokyčius vyko įstaigoje, kokị vaidmeni vaidino organizacijos vadovas ir kiti jos nariai. Taikant atvejo studijos metodą, pasirinktos trys Ukmergès rajono mokyklos, siekiant išsiaiškinti kaitos proceso raišką jose. Kaip teigia A. Valackienė (2016), remdamasi R. Yino (2009), atvejo studija būtina, jei pagrindinis darbe keliamas klausimas yra „kaip“. Šiame darbe kaip tik ir siekiama išsiaiškinti, kaip kaitos procesas lemia pokyčius bendrojo lavinimo mokykloje. Pažymėtina ir tai, kad bus atliekama kelių atvejų (ang. multiple-case) studija. Taip apsispręsta dèl to, kad didžiausia šio darbo pridètine verte laikomos rekomendacijos, kurios leistų užtikrinti pokyčių sẻkmingumą. 
Iš dalies struktūruotas interviu bus atliekamas su: Lietuvos Respublikos švietimo ir mokslo ministerijos Švietimo kokybès ir regioninès politikos departamento atstovais, kurie pagal kompetenciją atsakingi už Vilniaus apskrities teritoriją; Ukmergès rajono savivaldybės Švietimo ir sporto skyriaus atstovais; Ukmergès rajono mokyklų, kurių atvejai analizuojami šiame darbe, vadovais. Iš dalies struktūruoti interviu leis pagrịsti empirinio tyrimo rezultatus, įvertinti pokyčių mokyklose proceso sistemiškumą ir subjektyvius, įtaką minètam sistemiškumui darančius veiksnius.

III etapas. Pokyčių rezultatų vertinimas. Paskutiniame tyrimo etape, apibendrinant surinktą informaciją, bus vertinama kaitos proceso ịgyvendinimo ir pokyčių valdymo sinergija.

1 lentelèje pristatoma tyrimo logika / instrumentarijus, t. y. konkretūs elementai, leisiantys analizuoti, kaip ugdymo įstaigose vyko kaitos procesas, koks pokyčiu planas.

1 lentelè. Kaitos proceso ir pokyčių valdymo sinergiją atitinkančios dimensijos (sudaryta, remiantis ankstesnèse darbo dalyse aptartomis teorinėmis ižvalgomis)

\begin{tabular}{|c|c|}
\hline \multicolumn{2}{|r|}{ Mikrolygmuo (tirti pasirinktos bendrojo lavinimo mokyklos) } \\
\hline \multicolumn{2}{|r|}{ Kriterijai ir rodikliai } \\
\hline Lyderis & $\begin{array}{l}\text { Mokyklos vadovas imasi iniciatyvos vykdyti pokyčius, juos } \\
\text { aiškiai apibrěžia, nustato siekiamus tikslus, nuolat motyvuoja kitus } \\
\text { organizacijos narius tụ tikslu siekti; organizacijos nariams teikiama } \\
\text { išsami informacija apie visus pokyčiu igyvendinimo proceso etapus }\end{array}$ \\
\hline Individas & $\begin{array}{l}\text { I pokyčių procesą įtraukiami mokyklos, kaip organizacijos, nariai } \\
\text { (mokiniai, jų tèvai, mokytojai, kiti mokyklos darbuotojai), kurie } \\
\text { dalyvauja apibrěžiant bendrus pokyčiu tikslus, gauna konkrečias } \\
\text { užduotis, yra nuolat informuojami apie pasiektus tarpinius pokyčių } \\
\text { rezultatus ar kliūtis, trukdančias tuos pokyčius igyvendinti. Pokyčiu } \\
\text { procese dalyvauja kaip teisèti „savininkai“, atliekantys jiems skirtus } \\
\text { vaidmenis }\end{array}$ \\
\hline Bendruomenè & $\begin{array}{l}\text { I pokyčių procesą įtraukiama platesnė bendruomenė (vietos verslas, } \\
\text { nevyriausybinės organizacijos ir pan.), kuri informuojama apie } \\
\text { mokykloje vykstančius pokyčius, galinčius turèti ịtakos ne tik } \\
\text { mokyklos nariams, bet ir plačiajai bendruomenei (pavyzdžiui, } \\
\text { darbuotojų skaičiaus kaita, naujų mokinių pritraukimas, mokyklos } \\
\text { atliekamų funkcijų išplètimas ir pan.). Sudaromos galimybès } \\
\text { išsakyti savo nuomonę apie pokyčius mokykloje (vieši renginiai, } \\
\text { apklausos, dvišalės konsultacijos ir pan.) }\end{array}$ \\
\hline $\begin{array}{l}\text { Pokyčių } \\
\text { kompleksiškumas }\end{array}$ & $\begin{array}{l}\text { Pokyčiu procesas apima daugelị skirtingų sričių. Vyrauja supratimas, } \\
\text { kad kaita vienoje srityje lemia pokyčius kitoje, todèl ị visą kaitos } \\
\text { procesą žiūrima holistiškai }\end{array}$ \\
\hline
\end{tabular}




\begin{tabular}{|c|c|}
\hline \multicolumn{2}{|r|}{ Mezolygmuo (Ukmergès rajono savivaldybė) } \\
\hline \multicolumn{2}{|r|}{ Kriterijai ir rodikliai } \\
\hline $\begin{array}{l}\text { Savivaldybès } \\
\text { sprendimai }\end{array}$ & $\begin{array}{l}\text { Mokykloje kreipiamas dėmesys į savivaldybės tarybos ar mero } \\
\text { priimtus sprendimus: rengiami susitikimai su savivaldybės atstovais, } \\
\text { siekiant suprasti, kokių pokyčių pageidaujama savivaldybės lygiu. } \\
\text { Apie mokykloje priimtus sprendimus / pokyčių igyvendinimo gaires } \\
\text { reguliariai informuojama savivaldybė }\end{array}$ \\
\hline \multicolumn{2}{|c|}{$\begin{array}{l}\text { Makrolygmuo (valstybė: Lietuvos Respublikos Seimas, Lietuvos Respublikos } \\
\text { Vyriausybė, Lietuvos Respublikos švietimo ir mokslo ministerija) }\end{array}$} \\
\hline \multicolumn{2}{|c|}{ Kriterijai ir rodikliai } \\
\hline $\begin{array}{l}\text { Valstybės } \\
\text { lygiu priimami } \\
\text { sprendimai }\end{array}$ & $\begin{array}{l}\text { Mokyklos vadovai dideli dėmesị skiria valstybės lygiu priimamų } \\
\text { sprendimų / strategijų švietimo srityje analizei. Prireikus } \\
\text { konsultuojasi su valstybės institucijų atstovais ir siekia ịgyvendinti } \\
\text { šiuos sprendimus. Nuolat analizuojami ir kiti valstybès sprendimai } \\
\text { (ekonomikos, socialinės politikos, kitų sričių), kurie gali turèti įtakos } \\
\text { mokykloje vykstančiam kaitos procesui (pavyzdžiui, investicijų } \\
\text { skatinimas regione ar - atvirkščiai, dirbančių ịmonių pasitraukimas } \\
\text { ir pan.) }\end{array}$ \\
\hline
\end{tabular}

\section{Išvados}

1. Konceptualizuojant teorines įžvalgas, kurios atitinka kaitos procesą ir pokyčių valdymo lauką, bei nubrèžiant tyrimo metodologinį konstruktą, išryškinant švietimo kaitos ir pokyčių valdymo ugdymo įstaigose sinergijos ypatybes, plètota mokslinè diskusija: atlikta kaitos sampratos analizė leidžia teigti, kad klasikinẻ kaitos samprata tiktu ir švietimo kaitai apibūdinti, aiškinant, kad tai perèjimas iš vienos būsenos ị kitą. Tačiau švietimo santykis su kaita yra šiek tiek sudètingesnis, nes apima daugiau dedamuju ir visą visuomenę. Pirma, švietimo kaita visada siejama su pažanga. Antra, kaita atskleidžia proceso vientisumą ir visapusiškumą. Ji apima visą grandinę ịvykių: nuo švietimo politikos vietos kontekste bei politikos interpretavimo iki veiklos klasėje. Trečia, kaita yra neišvengiama, kai asmuo ir organizacija su ja besąlygiškai susiję. Švietimo kaita, kaip sąmoningų ir kryptingų pastangų darinys, natūralus socialinių dèsnių nulemtas procesas, kurio negalima stabdyti, o tik suteikti norimą tempą, pageidaujamą kryptị ir priimtinesnį pobūdị. Sèkmingą ugdymo įstaigos kaitą lemia tinkamai parinkta pokyčių strategija.

2. Straipsnyje aptartos trys teorinès tyrimo konstravimo prielaidos. Pirmoji, pasitelkus integruotą pokyčių valdymo modelį, kuris paaiškina tiek išorinius, tiek vidiniu elementus (mikrolygiu - individualų supratimą apie pokyčius; mezo- - lyderystę ir organizacijos identitetą; makro- - aplinką). 
Modelio aprèptyje analizuojami tiek išoriniai (makrolygmens), tiek organizacijų kultūros (mezolygmens), tiek individualūs (mikrolygmens) pokyčiai. Darbe modelis papildomas kita teorine ịžvalga, t. y. pokyčių procesų analizès lauku: prieš pokyčius; kai vyksta pokyčiai; pokyčiams pasibaigus, išryškinant, kad tris šio proceso elementus vieną su kitu sieja organizacijos identitetas. Trečioji teorinè ịžvalga padès atskleisti pokyčių sistemiškumo ugdymo įstaigose raišką, užtikrinant kaitos tvarumą. Teorinèms įžvalgoms konstruoti pasitelkta kompleksiškumo teorija. Remiantis šiomis teorinėmis ižzalgomis, pasirinktų ugdymo įstaigų pavyzdžiu pateikiamas tyrimo metodologinis konstruktas, pristatytos tyrimo dimensijos, kriterijai ir rodikliai.

\section{Literatūra}

Bagdonas, A. (2016). Vadovo veiklos funkciju raiškos tyrimas mokyklos kaitos procese. Prieiga internete: $\quad$ https://dspace.kauko.lt/bitstream/handle/1/1171/JVMF_menasdizainas_ konferencija_2016\%20\%281\%29_optimize.pdf?sequence [žiūrèta 2018-06-17]].

Bennis, W., Nanus, B. (1998). Lyderiai: atsakomybès strategija. Vilnius: Algarvè.

Dainty, P., Kakabadse, A. (1990). Organizational change: A strategy for successful implementation. Journal of business and psychology 4(4): 463-481.

Ellstrom, P. E. (1984). Rationality, Anarchy, and the Planning of Change in Educational Organizations. Study of Problem Solving and Planning of Change in Small Work Groups. Linkoping. Linköping University, Department of Education and Psychology.

Fullan, M. (1998). Pokyčiu jègos. Vilnius: Tyto alba.

Gečienè, E. (2003). Pokyčiu visuomeneje sąsaju su švietimo kaita paieška. Vilnius: Ciklonas.

Hargreaves, A. (2008). Mokymas žiniu visuomeneje. Švietimas nesaugumo amžiuje. Vilnius: Homo liber. Hopkins, D., Ainscow, M., West, M. (1998). Kaita ir mokyklos tobulinimas. Vilnius: Tyto alba.

Husen, T. (1990). Strategy Rules for Educational Reform: An International Perspective on the Spanish Situacion. Education and the Global Concern. Oxford: Pergamon Press.

Yin, R. K. (2009). Case study research: Design and methods. 4th ed. Thousand Oaks, CA: Sage.

Jacobs, G., Witteloostuijn, A., Christe-Zeyse, J. (2013). A theoretical framework of organizational change. Journal of Organizational Change Management 26 (5): 772-792.

Jenlink, P. M., Reigeluth, C. M., Carr, A. A., Nelson, L. M. (1998). Guidelines for facilitating systemic change in school districts. Prieiga internete: http://www.indiana.edu/ syschang/decatur/new members/pdf_documents/gste_systems-research.pdf [žiūrèta 2018-08-12].

Jovaiša, L. (2007). Enciklopedinis edukologijos žodynas. Vilnius: Gimtasis žodis.

Jucevičius, R., Jucevičienè, P., Janiūnaitè, B., Cibulskas, G. (2003). Mokyklos strategija. Strateginio vystymo vadovas. Kaunas: Žinių visuomenės institutas.

Kubilienè, R. (2003). Vadovo vaidmuo skatinant tobulintis profesijos mokytojus. Profesinis rengimas: tyrimai ir realijos 6: 207-211.

Kuhn, T. S. (1962). The Structure of Scientific Revolutions. Chicago: University of Chicago Press.

Lindsay, B., Smit, E. (2018). How the implementation of organizational change is evolving. McKinsey\&Company. Prieiga internete: https:/www.mckinsey.com/business-functions/ mckinsey-implementation/our-insights/how-the-implementation-of-organizational-change-isevolving [žiürèta 2018-05-21].

Lotich, P. (2017). 8 steps to implementing successful organizational change. Prieiga internete: https:// thethrivingsmallbusiness.com/8-steps-to-implementing-successful-organizational-change [žiūrèta 2018-08-09]. 
Mason, M. (2016). Is Thorough Implementation of Policy Change in Education Actually Possible? What Complexity Theory Tells Us About Initiating and Sustaining Change. European Journal of Education 51(4). DOI: 10.1111/ejed.12193. 437-440. Prieiga internete: https://onlinelibrary. wiley.com/doi/abs/10.1111/ejed.12193 [žiūrèta 2018-08-11].

Monkevičienė, O. (2008). Ikimokyklinio ir priešmokyklinio ugdymo(si) turinio kaitos tendencijos. Pedagogika 91: 66-72.

Smith, R., King, D., Sidhu, R. Skelsey, D. (2014). The effective change manager's handbook. Prieiga internete: https://books.google.lt/books?id=gNAZBQAAQBAJ\&printsec=frontcover\&dq=s

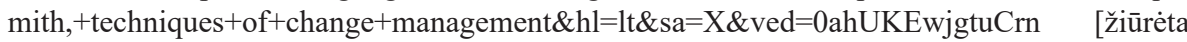
2018-08-12].

Stoll, L., Fink, D. (1998). Keičiame mokykla. Vilnius: Margi raštai.

Targamadzè, V. (1996). Švietimo organizacijų elgsena. Kaunas: Technologija.

Valackienè, A. (2016). Towards a framework for case study research: methodology and practical implementation. CISABE'2016: 6th International conference on Changes in social and business environment, April 28-29, 2016, Panevėžys, Lithuania. Bologna: MEDIMOND, p. 65-70.

Wallace, M., Pocklington, P. (2001). Sudètingų švietimo sistemos pokyčių valdymas. Prieiga internete: http://www.mtp.smm.lt/dokumentai/InformacijaSvietimui/UzsStraipsniuVertimai/ Wallace_nygos_vertimas.doc [žiūrèta 2018-08-12].

Želvys, R. (1998). Švietimo reformos. Vilnius: Švietimo studijų centras.

Želvys, R. (1999). Švietimo vadyba ir kaita. Monografija. Vilnius: Garnelis.

Želvys, R. (2003). Švietimo organizaciju vadyba. Vilnius: VU leidykla.

\title{
THE SYNERGY OF THE PROCESS OF CHANGE AND CHANGE MANAGEMENT IN THE EDUCATIONAL INSTITUTIONS: METHODOLOGICAL CONSTRUCT OF THE RESEARCH
}

\author{
Asta Valackienė, Vaida Želnienė, Kaunas University of Technology \\ Summary
}

The authors analyse the process of change in the article and emphasize that the social change on the international and national level encourages the change management field in the education system of a particular country. These ideas stimulate the following problem statement: what factors lead to the synergy of the process of change and change management in the educational institutions? The authors encourage scientific discussion and invite to analyse the reasons for differences of the process of change and its results in the educational institutions taking into account that this process is determined by similar internal and external factors. The authors state that the systemic change management plays a decisive role in the process of 
change of an organisation. Thus, the aim of the analysis is to present the methodological concept of the research and to discuss the synergy of the process of change and change management in the educational institutions. In order to reach the aim, a logical sequence analysis of social phenomenon has been created. It reflects the tasks of the analysis: the concept of the process of change and change management is justified theoretically; regularities and principles of educational change are then presented; a theoretical background is used seeking to highlight the application of a model of integrated change management in the process of change of educational institutions; research methodology has been formulated; dimensions, criteria and indicators of the research have been identified.

After the conceptualization of the process of change and change management field, reveal of synergy of educational change and change management, it was concluded that the classical concept of change may also be applied to the description of educational change and to the explanation that it is a transition from one state to another.

However, the relation between education and change is more complex as it encompasses more components and the whole society. The main element in this concept is the fact that the educational change is always related to progress. In addition to this, the change shows the integrity and comprehensiveness of the process. The change includes the set of events: from the education policy through the local context and policy interpretation to the activities with the students. What is more, the change is inevitable while a person and an organisation are interrelated unconditionally. The educational change may be treated either as a construct of conscious and purposeful or as a natural process determined by the social laws. The latter process can be neither started nor stopped, it may only be given the desired pace, direction and acceptable character. The successful improvement of a school is determined by the strategy chosen properly which guarantees useful changes. It is important to notice that the synergy of change and change management is becoming obvious phenomenon. The forms of change, the stages of the process of change as well as successful techniques of the process of change are analysed in the article.

Three theoretical assumptions are discussed in order to design the research. First, the integrated change management model is being applied. The model explains external and internal elements (micro level: individual understanding about the changes; meso level: leadership and organisational identity; macro level: general environment). Within the limits of the model, external (macro level), organisational culture (meso level) and individual (micro level) changes are being analysed. The authors supplement this theoretic model with the second theoretic insight which emphasizes the analysis field of the process of changes. This process 
is composed of the period before changes, period during which the changes take place and the period after the changes. It is emphasized that all three elements of the process are encompassed by organisational identity. Third, the expression of systemic changes in educational institutions is being discussed. In order to ensure sustainability of the changes, the theory of complexity is being applied. This theory includes the elements necessary for the analysis of systemic changes in educational institutions.

On the basis of the theoretic constructs of the concepts of the process of change and change management, the authors present the research design in the third part of the work: the dimensions, criteria as well as indicators are presented in it. These elements will allow assessing the synergy of the process of change and change management in the particular organisations. The schools of general education of Ukmerge district municipality have been chosen for the analysis. These educational institutions reflect the required changes in education system at the regional level. The stages of the research together with the methods are being discussed as well.

The authors invite for scientific discussion while discussing the synergy between the process of change and the change management in the system of education and emphasizing that two different factors give larger impact and socioeconomic benefits if they are used together. It is expected that the questions raised in the article and the methodological construct of the research will encourage deeper scientific discussions and will make an input to better results of interaction between the implementation of the process of change and change management of the system of education. 